\title{
Biblische TeXTe VOM GLüCK: LigPUNTE VIR LESERS
}

Book Title:

Zum Leuchten bringen Biblische Texte vom Glück

\section{Book Cover:}

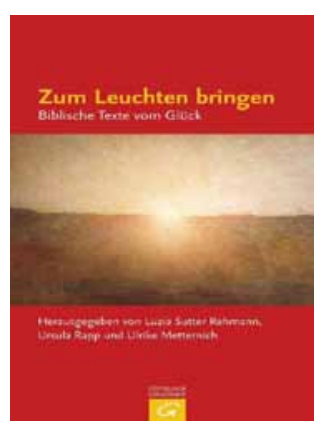

Authors:

Herausgegeben von Luzia S. Rehmann, Ursula Rapp and Ulrike Metternich

ISBN:

978-3-579-05405-6

\section{Publisher:}

Gütersloher Verlagshaus (a division of Verlagsgruppe Random House),

Güterloher; 2006, pp. 207,

$€ 19.95^{*}$

*Book price at time of Review

\section{Review Title:}

Biblische Texte vom Glück:

Ligpunte vir lesers

\section{Reviewer:}

Peter Nagel

\section{Affiliation:}

Departement Nuwe Testament, Universiteit van Pretoria, Pretoria, Suid-Afrika

email: peter.nagel@up.ac.za

Postal address:

Posbus 578, Lanseria 1748 Suid-Afrika

\section{How to cite this book} review:

Nagel, P., 2010, 'Biblische Texte vom Glück: Ligpunte vir lesers', Verbum et Ecclesia 31(1), Art. \#419, 2 pages. DOI: $10.4102 /$ ve.v31i1.419

This review is available at: http://www.ve.org.za

(c) 2010. The Authors. Licensee: OpenJournals Publishing. This work is licensed under the Creative Commons Attribution License.
Die bundel bestaan uit 12 bydraes deur verskillende skrywers, naamlik Ursula Rapp (spesialis in die eksegese van die Ou Testament, Universiteit van Luzern), Ulrike Metternich (feministiese teoloog), Luzia S. Rehmann (titulêre professor in die Nuwe Testament, Universiteit van Basel), Nancy C. Pereira (Metodistiese pastoor in die ekumeniese pastorale bediening in Porto Alegre, Brasilië) en Luise Schottroff (Protestantse feministiese teoloog, Universiteit van Keulen). Hierdie skrywers is 'n groep medewerkers wat hulle, veral uit 'n feministiese perspektief, vir sosiale geregtigheid en regverdigheid beywer. Sommige van die skrywers is ook betrokke by die Duitse Bybelvertalingsprojek, Bibel in gerechter Sprache, wat ten doel het om onder andere juis op sosiale geregtigheid te konsentreer.

Die bydraes is in agt kategorieë verdeel, naamlik Euangelion, Glücklich ist, Konzentrationsübung, Engel, Augen fangen dich auf, Verborgenes Licht, Freude II en Glück wünschen, waarin die skrywers geluk nie aan die toekomstige ewigheid oorlaat nie, maar dit in die alledaagse soek. Dit is onder meer die skrywers se bedoeling om te besin oor hoe God Hom in elkeen se lewe sigbaar maak. Hulle poog om hierdie doelwitte te verwesenlik deur hul huidige kontekste met Bybeltekste in gesprek te bring wat sowel eksplisiet as implisiet oor geluk handel.

Ursula Rapp benader die tema uit die hoek van die Ou Testament. In haar eerste bydrae onder die tema Die Seligpreisungen der Bibel als Glïckssprache fokus sy op Psalm 1. Sy kom tot die gevolgtrekking dat hierdie psalm die Tora as bron van die lewe beskou, en geluk lê dus in die nadenke en uitleef daarvan. In die ander twee bydraes uit haar pen beklemtoon Rapp die 'geluk' van Sarai en Hanna. Die tipe geluk wat sy hier wil beskryf, is geluk wat sigself met liefde, erotiek en lag sowel as met die realiteit van vrees bemoei.

Ulrike Metternich steun op en besin oor die bydrae van Dorothee Sölle, 'n Duitse liberale teoloog (19232003), wat onder andere van mening was dat geluk 'n toestand van stilwees behels; geluk is om die huidige met die verwagting te verweef. Metternich benader die vraag na geluk deur ook na 'moderne' gedigte te verwys wat juis op geluk en die soeke daarna konsentreer. Metternich se twee bydraes in die bundel, in samewerking met Ursula Rapp, handel oor die verskynsel dat geluk 'n positiewe soort mag (en bemagtiging) kan teweeg bring. Hiervoor doen die twee outeurs breedvoerig verslag van 'n onderhoud met Michaela Bank ('n Katolieke non) en Ingrid Schmid ('n verpleegster), en verwys daarna vlugtig na Sarai en Hanna. Hierdie bydrae word gevolg deur Ursula Rapp se beoordeling van Sarai en Hanna se lewe wat betref geluk al dan nie.

Luzia S. Rehmann benader geluk, of die nadenke daaroor, deur na sprankeling en lig as metafore vir geluk te verwys. Rehmann beperk nie die metafore van lig en sprankeling tot mense nie, maar pas dit ook op dae, jare en kosbare geleenthede toe. Sy verwys na die bekende gedeelte in Lukas 11:33-36, wat impliseer dat werklike geluk nie verdoesel moet/kan word nie. Sy betoog dat die sigbaarheid van lig God se heiligheid weerspieël, terwyl die teendeel skynheiligheid impliseer. Die draers van geluk beskik dus oor geweldige potensiaal, maar daarmee saam kom ook 'n ernstige verantwoordelikheid: Die uitstraal van lig, wat dit ook al simboliseer, kan immers sowel positiewe as negatiewe gevolge hê. In haar volgende bydrae in die bundel ondersoek Rehmann die Griekse woord kaıpó $($ kairos) in Lukas 13 , en sluit só by Luis Schottroff se bydrae aan, met'n blik op geluk in moeilike tye. Sy benader Lukas 13 betreklik uitvoerig, van waar sy die ritme van geluk beklemtoon.

Nancy C. Pereira dryf die spanning tussen genade en swaarkry, wat mettertyd geluk meebring, op die spits deur haar baie praktiese benadering in die verwysingsraamwerk van die Latyns-Amerikaanse teologie. Pereira maak dit duidelik dat sy geen teoretiese verhandeling wil skryf of haar op die woordeboek wil beroep wanneer sy haar oor geluk uitspreek nie, maar dat sy veel eerder 'n lofrede wil voorhou wat in 'n geleefde realiteit veranker is. Sy stel hoofsaaklik belang in die verloop van geleefde geluk - om deur middel van feeste en ander rituele die fisiese en simboliese vermoë as't ware aan te wakker ten einde die slegte van die realiteit vir 'n meer konstruktiewe denkraamwerk te verruil. Sodanige konstruktiewe raamwerk behels die vermoë om voort te lééf en te glo. Sy beroep haar dan ten slotte op 'n paar aanhalings uit Spreuke.

Luise Schottroff se ondersoek na die tema van geluk in Bybelse tekste geskied uit'n gelykenisperspektief. Buiten die Ou-Testamentiese tekste Psalm 79:1 en 4 Esra 10:50 waarna sy verwys, verreken sy ook Lukas 13:1-9 in hierdie verband. Schottroff behandel ook ander gelykenisse uit die Evangelies waarin geluksmomente voorkom. Die koninkryksmotief wat deur die gelykenisse toeganklik word, word dan Schottroff se uitgangspunt, naamlik dat die nabyheid van God juis in die gemeenskaplike maaltyd tot sy volle reg kom. Dit is juis dáár wat die speelveld van die wat honger het, die wat dors het, en die wat het en nié het nie, gelykgemaak word. Sy beskryf dit só: 'Dem Abendmahl, ist das Glück Gottes zu ahnen, zu schmecken, zu sehen, zu kosten.'

Luzia S. Rehmann het die laaste woord in die bundel met haar bydrae getiteld Glückelchen Reflexionen über Herkunft und Werdegang eines fremdes Wortes, wat oor geluk en die herkoms van dié woord handel. Sy struktureer die aanbieding van haar data onder die volgende hoofde:

- Heidenzeit ('n vlugtige verwysing na die Romeinse godin wat met geluk of voorspoed geassosieer is) 
- Paarungsversuche (die soeke na semantiese verwantskappe)

- Schwierige Zeiten (geluk by die ongeluk)

- Neuzeit (potensiaal vir geluk)

- Auszeit (geluk in stilte en in tye van rus en besinning)

- Umwertung (herwaardering, herevaluering)

- Auferstehung (geluk te midde van die Opstanding)

Die skrywers slaag daarin om, in hul nadenke oor relevante Bybeltekste en geluk, die materiaal vir lesers toeganklik te maak. Hulle is meesters van die kuns om eksegeties-filosofiese sowel as sosiaal-antropologiese data eenvoudig en verteerbaar vir lesers aan te bied. Hierdie bundel moenie beskou word as 'n poging om streng wetenskaplik met daardie Bybeltekste om te gaan waarin geluk as tema of konsep hanteer word nie. Die tekste wat die skrywers in die bundel behandel, word nie aan literêre analises of uitvoerige eksegese onderwerp nie, en dus is daar op sommige plekke in die boek 'n gebrek aan besonderhede. Die skrywers tree in die eerste instansie eerder in gesprek met die Bybelse teks en hul eie konteks, en skep sodoende ruimte dat die teks weer in 'n nuwe konteks tot uiting kan kom. Die bydraes volg oor die algemeen 'n inherent tematiese benadering ten einde nadenke oor geluk aan die hand van die Bybelteks toeganklik te maak. Hierin slaag dit wel. Die bydraes in hierdie bundel kan van groot waarde wees vir mense wat na geluk smag - juis diegene wat pyn, swaarkry en seer beleef. Die inhoud van die bundel sal veral byval vind by lesers in 'n Afrikaanse idioom. 